\title{
Anti-Toxoplasma IgG assays: What performances for what purpose? A systematic review
}

\author{
Florence Robert-Gangneux* and Hélène Guegan \\ Université de Rennes, CHU Rennes, Inserm, EHESP, Irset (Institut de Recherche en Santé Environnement Travail), UMR_S 1085, 35000 \\ Rennes, France
}

Received 23 February 2021, Accepted 31 March 2021, Published online 26 April 2021

\begin{abstract}
Chronic infection with Toxoplasma gondii is attested by the detection of specific anti-Toxoplasma IgG. A wide panel of serologic methods is currently marketed, and the most suitable method should be chosen according to the laboratory resources and the screened population. This systematic review of evaluation studies aimed at establishing an overview of the performances, i.e. sensitivity, specificity, positive predictive value (PPV) and negative predictive value (NPV) of marketed anti-Toxoplasma IgG assays, and discussing their technical characteristics to guide further choice for routine diagnostic use. According to PRISMA guidelines, the search performed in PubMed and Web of Science databases recovered 826 studies, of which 17 were ultimately included. Twenty commercial anti-Toxoplasma IgG assays were evaluated, in comparison with an accepted reference method. Most of them were enzyme-immunoassays (EIAs, $n=12$ ), followed by agglutination tests $(n=4)$, immunochromatographic tests $(n=3)$, and a Western-Blot assay (WB, $n=1$ ). The mean sensitivity of IgG assays ranged from $89.7 \%$ to $100 \%$ for standard titers and from $13.4 \%$ to $99.2 \%$ for low IgG titers. A few studies pointed out the ability of some methods, especially WB to detect IgG early after primary infection. The specificity of IgG assays was generally high, ranging from $91.3 \%$ to $100 \%$; and higher than 99\% for most EIA assays. The PPV was not a discriminant indicator among methods, whereas significant disparities (87.5\%-100\%) were reported among NPVs, a key-parameter assessing the ability to definitively rule out a Toxoplasma infection in patients at-risk for opportunistic infections.
\end{abstract}

Key words: Anti-Toxoplasma IgG, Diagnosis, Serology, Toxoplasmosis, Sensitivity, Specificity.

L'infection chronique à Toxoplasma gondii est attestée par la détection d'IgG anti-Toxoplasma spécifiques. Un large panel de méthodes sérologiques est actuellement commercialisé, et le choix d'une méthode doit être adapté aux ressources du laboratoire ainsi qu'à la population ciblée. Cette revue systématique des études d'évaluation visait à établir une vue d'sensemble des performances, c'est-à-dire la sensibilité, la spécificité, la valeur prédictive positive (VPP) et la valeur prédictive négative (VPN) des kits commercialisés pour la détection d'IgG anti-Toxoplasma, et à discuter leurs caractéristiques techniques pour guider le choix pour un usage diagnostique de routine. Selon les directives PRISMA, la recherche effectuée dans les bases de données PubMed et Web of Science a permis de retrouver 826 études, dont 17 ont été définitivement incluses. Vingt dosages commerciaux d'IgG anti-Toxoplasma ont été évalués, en comparaison avec une méthode de référence. La plupart des tests étaient des méthodes de dosage immuno-enzymatique $(n=12)$, d'agglutination $(n=4)$, immunochromatographiques $(n=3)$ et de WesternBlot $(n=1)$. La sensibilité moyenne des dosages IgG variait de 89,7 à $100 \%$ pour les titres standards et de $13,4 \%$ à 99,2 \% pour les faibles titres d'IgG. Quelques études ont souligné la capacité de certaines méthodes, en particulier le Western-Blot, à détecter les IgG au cours d'une primo-infection. La spécificité des tests IgG était généralement élevée, allant de $91,3 \%$ à 100, et supérieure à $99 \%$ pour la plupart des tests immuno-enzymatiques. La VPP n'était pas un indicateur discriminant entre les méthodes, alors que des disparités significatives $(87,5 \%$ à $100 \%$ ) ont été rapportées entre les VPN, un paramètre-clé reflétant la capacité d'un test à éliminer formellement une toxoplasmose chez les patients à risque d'infections opportunistes.

\section{Introduction}

Toxoplasmosis is a foodborne or waterborne protozoan infection, with an estimated seroprevalence of $30 \%$ worldwide
[20]. However, there are huge differences in prevalence rates among geographical areas, mainly in relation to climate, dietary and social habits, and socioeconomic levels. Infection with Toxoplasma gondii is often unnoticeable and after a first step of

\footnotetext{
*Corresponding author: Florence.robert-gangneux@univ-rennesl.fr
} 
systemic dissemination, the parasites become encysted and remain lifelong in various anatomic sites, notably the brain, the muscles, and the retina. Serology is an important tool for the diagnosis of toxoplasmosis and is widely used to determine whether a pregnant woman is at risk of primary infection during pregnancy or if an immunocompromized patient is at risk of Toxoplasma reactivation. Importantly, toxoplasmosis can lead to congenital infection when acquired by a non-immune pregnant woman, with a rate of transmission and severity depending on the trimester of pregnancy at maternal infection. Additionally, encysted parasites can reactivate in case of immune suppression (HIV infection, transplantation, immunosuppressive therapies, etc.) and cause encephalitis, retinochoroiditis, or disseminated infection with a high mortality rate [6, 21]. Knowledge of the immune status allows (i) if negative, to provide targeted clinical counseling to avoid infection, and (ii) if positive, to include toxoplasmosis among possible opportunistic infections in immunocompromized patients with evocative clinical signs, or to prescribe chemoprophylaxis [6]. Usually, Toxoplasma serology relies on the detection of both specific $\operatorname{IgG}$ and $\operatorname{IgM}$, allowing precise interpretation of results, taking advantage of the kinetics of isotypes detection. However, antiToxoplasma $\mathrm{IgG}$ is the key parameter to indicate past infection or to confirm primary infection, as the sole detection of antiToxoplasma IgM is not conclusive. Therefore, the specificity and sensitivity of anti-Toxoplasma IgG assays is crucial. Many $\mathrm{IgG}$ assays are marketed worldwide, either manual or automated, and are based on various detection methods including agglutination assays, western-blot assays, enzyme immunoassays (EIAs), and immunofluorescence assays. They have variable performances and thresholds of detection, although most of them are supposed to be standardized upon an international standard [17, 27]. More recently, rapid diagnostic tests (RDTs) have also been developed.

The choice of the technique may depend on the situation and the targeted goal: Will the assay be used in accredited laboratories of high-income countries? Will it be adapted to climate and primary care structures of low-income countries? This systematic review aimed at compiling all evaluation studies on anti-Toxoplasma IgG assays, to provide an accurate view on the performance and practicability of marketed tests and help guide the choice of an IgG assay.

\section{Methods}

The study was performed according to the Preferred Reporting Items for Systematic review and Meta-Analyses (PRISMA) guidelines. Published literature was searched for in the PubMed database, combining medical subject headings (MeSH) terms as follows: (((“Toxoplasmosis/diagnosis”[Mesh]) AND "Serologic Tests”[Mesh])) NOT “Toxoplasmosis, Congenital”[Mesh], and restricted to "humans", "abstract available", "English" language and timespan 1990-2020 (October 28th). Other searches were done using the following keywords: anti-Toxoplasma IgG, toxoplasmosis serology or toxoplasmosis assay in PubMed (restricted to the fields "title/abstract") and Web of Science databases, applying the same restrictions. For the Web of Science database, the search terms were "toxoplasmosis serology" or "anti-toxoplasma IgG" or "toxoplasmosis assay", and results were further focused on the following research areas: "Parasitology", "Infectious Diseases", "Microbiology" and "Medical Laboratory Technology" and refined with "evaluation", "comparison", or "performance" terms. All references retrieved were screened one by one, and only studies evaluating the performance of commercial serological assays by comparison to a well-recognized reference method were included for analysis.

\section{Data extraction}

All selected articles were studied for further inclusion. Data collected were: first author name, publication year, country of study, study design, population studied, sample size, diagnostic method evaluated, reference method used, results of sensitivity, specificity, and positive predictive value (PPV) and negative predictive value (NPV), if relevant.

\section{Statistics}

Sensitivity was calculated from the results obtained for all positive sera, referring to the reference method used. Results obtained in the Grey Zone (GZ) were considered negative results, unless they were excluded by the authors and detailed results were not provided (one study). Sensitivity was calculated as: number of true positive results/number of seropositive patients. Specificity was calculated as follows: number of negative results/number of seronegative patients + number of false-positive results. PPV was calculated as the number of true-positive results/number of true-positive results + number of false-positive results. NPV was calculated as the number of true-negative results/number of true-negative results + number of false-negative results. When needed, sensitivity, specificity, PPV or NPV were re-calculated from the authors' data to allow homogeneous comparison among studies regarding GZ results.

When several studies evaluated the same assay, results for sensitivity and specificity were presented as mean and range. Wherever appropriate, sensitivity obtained on low-IgG sample collections was presented separately.

Graphs were constructed using GraphPad Prism v6 software.

\section{Results}

\section{Articles included}

The results of the various searches are described in Supplementary Table 1. All studies dealing with prevalence analysis, animal studies, experimental or research methods and simple correlation studies were discarded. After careful reading of 826 titles/abstracts, 30 eligible articles were included for thorough reading and analysis. Thirteen articles were further excluded, either because they provided vague results or merged $\mathrm{IgG/IgM} \mathrm{results} \mathrm{(three} \mathrm{studies),} \mathrm{or} \mathrm{used} \mathrm{an} \mathrm{in-house} \mathrm{or} \mathrm{another}$ EIA method as the gold standard or no reference method at all (six studies), or used methods which are no longer marketed (three studies), or included a too small number of sera $(<100)$ (one study). Finally, 17 studies were included in the analysis (Fig. 1). 


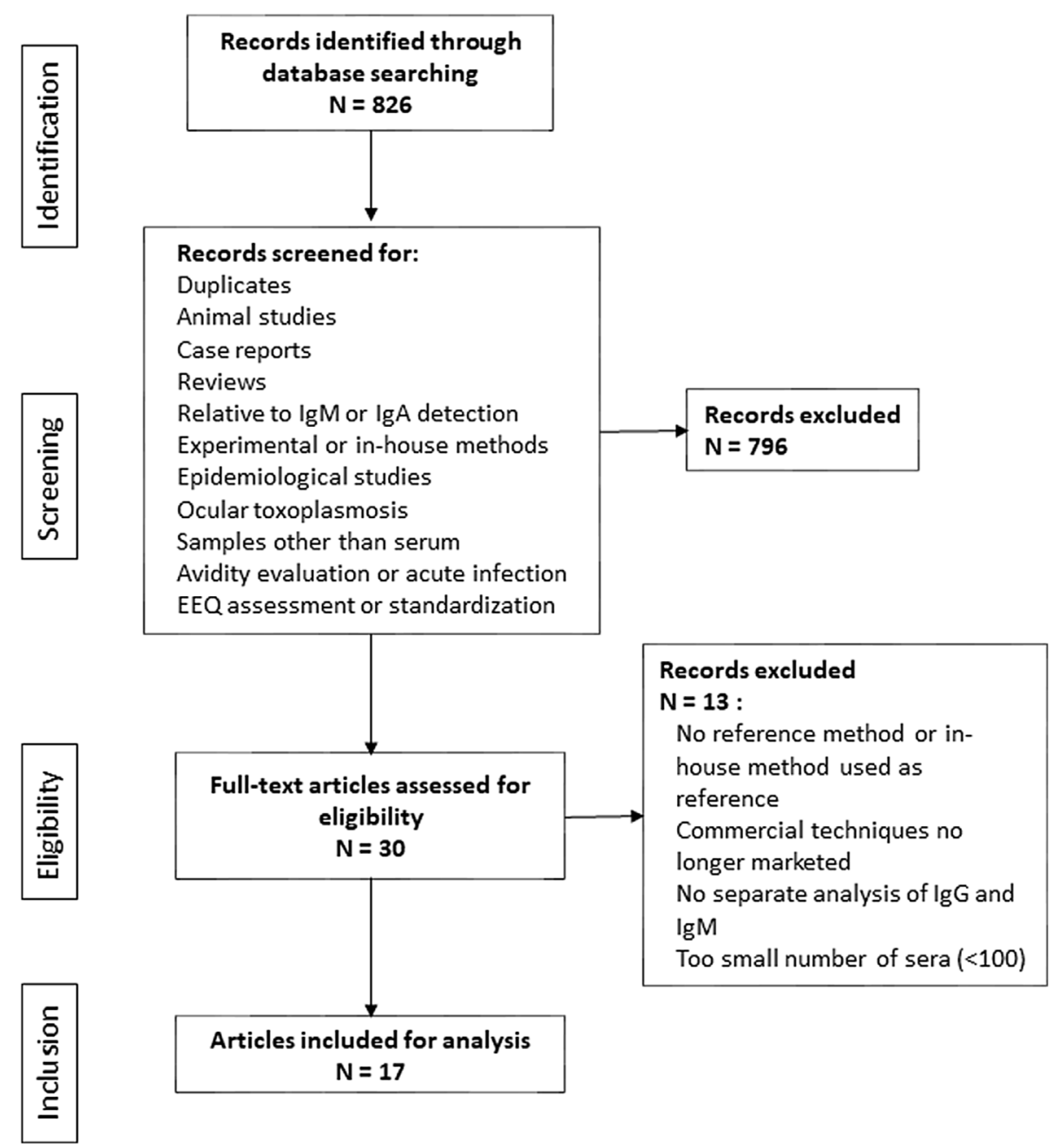

Figure 1. Flow chart of article selection for review.

\section{Methods evaluated}

Overall, the 17 studies evaluated 28 methods for the detection of anti-Toxoplasma $\mathrm{IgG}$, of which 8 were no longer marketed in 2020; therefore, we focused on results obtained on the 20 remaining assays listed in Table 1 . They consisted of agglutination assays (latex agglutination or hemagglutination, $n=4)$, EIA ( $n=12)$ using various detection systems or matrices (microplate enzyme-linked immuno-sorbent assay (ELISA), microparticle enzyme immunoassay (MEIA), enzyme-linked fluorescent assays (ELFA), chemiluminescent microparticle immunoassay (CMIA), electrochemiluminescence immunoassay (ECLIA)), western-blot assay $(n=1)$ and RDT based on immunochromatographic assays (ICT, $n=3$ ). There was no evaluation of immunofluorescence assays. Half of the assays were evaluated in only one study; the most frequently evaluated assays were Architect Toxo $\operatorname{IgG}^{\circledR}$, Elecsys Toxo $\operatorname{IgG}^{\circledR}$ and Vidas Toxo $\operatorname{IgGII}^{\circledR}$ (Table 1). Most studies were based on a selection of sera from a bank, while only three studies included consecutive non-selected sera [12-14], of which one mixed both selected and prospectively included sera [13]. The dye-test (DT) was the most frequently used method to confirm discrepant results between compared assays (10 studies), associated with immunofluorescence assay (IFA) in three studies.
The WB Toxo IgGII ${ }^{\circledR}$ assay was used as a reference method in six studies. For the two remaining studies [19, 23], the reference method used was a combination of several immunoassays.

\section{Sensitivity}

The mean sensitivity of $\mathrm{IgG}$ assays on routine sera ranged from $89.7 \%$ to $100 \%$ (Table 2). Eleven out of 20 assays had sensitivity $\geq 97 \%$. The mean sensitivity of each test is represented in Figure 2. Some manual methods had similar sensitivity rates to EIA. Studies evaluating the ability to detect low IgG titers were less numerous and yielded sensitivities ranging from $13.4 \%$ to $99.2 \%$ [4, 5, 13, 23, 24, 26]. The EIA assays displaying the poorest and the highest sensitivity in this setting were the Access Toxo IgGII ${ }^{\circledR}$ and the Elecsys Toxo $\operatorname{IgG}^{\circledR}$, respectively (Table 2). Among manual methods, the WB Toxo IgG II $^{\circledR}$ had the best sensitivity (99.2\%) to detect low IgG titers. Among agglutination tests, the Toxo-HAI ${ }^{\circledR}$ displayed the best sensitivity both on standard and low IgG titers (100\% and $97 \%$, respectively), but yielded $4.3 \%$ false-positive results with sera of patients with various interfering diseases [26]. Other agglutination assays $\left(\right.$ Toxolate $^{\circledR}$, Toxocell ${ }^{\circledR}$, and Pastorex Toxo $^{\circledR}$ ) performed well on standard IgG titers but not on low 
Table 1. Toxoplasma IgG commercial methods included: type of assay, number of evaluation studies, and population studied.

\begin{tabular}{|c|c|c|c|c|c|c|c|c|}
\hline Technique & Firm & Type of method & $\begin{array}{l}\text { Threshold } \\
\text { (IU/mL) }\end{array}$ & $\begin{array}{l}\text { No of } \\
\text { studies }\end{array}$ & $\begin{array}{c}\text { Population } \\
\text { studied }\end{array}$ & $\begin{array}{c}\text { No of } \\
\text { sera }\end{array}$ & $\begin{array}{c}\text { No of } \\
\text { IgG-positive }\end{array}$ & References \\
\hline Access Toxo IgG II ${ }^{\circledR}$ & Beckman Coulter Inc. & MEIA, automated & $7.5 \leq x<10.5$ & 2 & $\begin{array}{l}\text { Pregnant women } \\
\text { Low IgG }\end{array}$ & 760 & 257 & {$[4,14]$} \\
\hline Advia Centaur Toxo $\operatorname{IgG}^{\circledR}$ & Siemens Healthineers & CMIA, automated ${ }^{£}$ & $6.4<x \leq 10$ & 1 & Miscellaneous & 406 & 207 & [24] \\
\hline Architect Toxo $\operatorname{IgG}^{\circledR}$ & Abbott & MEIA, automated ${ }^{£}$ & $1.6 \leq x<3$ & 5 & $\begin{array}{l}\text { Pregnant women } \\
\text { Low IgG } \\
\text { Miscellaneous }\end{array}$ & 2992 & 773 & {$[4,7,13,16,24]$} \\
\hline AxSYM Toxo $\operatorname{IgG}^{\circledR}$ & Abbott & MEIA, automated ${ }^{£}$ & $2 \leq x<3$ & 3 & $\begin{array}{l}\text { Pregnant women } \\
\text { Miscellaneous }\end{array}$ & 1555 & 638 & {$[7,14,24]$} \\
\hline BioPlex 2200 ToRCH IgG/IgM ${ }^{\circledR}$ & BioRad & MFA, automated & $9 \leq x<12$ & 1 & Miscellaneous & 162 & 139 & [9] \\
\hline Elecsys Toxo $\operatorname{IgG}^{\circledR}$ & Roche Diagnostics & ECLIA, automated ${ }^{f}$ & $1 \leq x<30$ & 5 & $\begin{array}{l}\text { Pregnant women } \\
\text { Low IgG } \\
\text { Miscellaneous }\end{array}$ & 2214 & 1398 & {$[4,14,18,23,24]$} \\
\hline Immulite 2000 anti-Toxoplasma $\operatorname{IgG}^{\circledR}$ & Siemens Healthineers & MEIA, automated & $6 \leq x<8$ & 2 & $\begin{array}{l}\text { Miscellaneous } \\
\text { Pregnant women }\end{array}$ & 655 & 348 & {$[14,19]$} \\
\hline Liaison Toxo IgG II ${ }^{\circledR}$ & Diasorin & CMIA, automated ${ }^{\mathfrak{f}}$ & $7.2 \leq x<8.8$ & 4 & $\begin{array}{l}\text { Low IgG } \\
\text { Miscellaneous }\end{array}$ & 1381 & 460 & {$[4,16,23,24]$} \\
\hline $\begin{array}{l}\text { OnSite Toxo } \operatorname{IgG} / \operatorname{IgM} \text { Combo } \\
\text { Rapid Test }{ }^{\circledR}\end{array}$ & CTK Biotech & $\mathrm{ICT}$, manual ${ }^{£}$ & & 1 & Miscellaneous & 310 & 170 & [8] \\
\hline Pastorex $^{\circledR}$ & BioRad & Agglutination $^{£}$ & & 1 & Miscellaneous & 589 & 344 & [26] \\
\hline Platelia Toxo $\operatorname{IgG}^{\circledR}$ & BioRad & $\begin{array}{l}\text { Microplate ELISA, } \\
\text { automated }^{f}\end{array}$ & $6 \leq x<8$ & 3 & $\begin{array}{l}\text { Low IgG } \\
\text { Miscellaneous }\end{array}$ & 1436 & 491 & {$[4,10,24]$} \\
\hline TGS TA Toxo IgG/IDS-iSYS ${ }^{\circledR}$ & TGS Technogenetics & MEIA, automated & $>1.5$ & 2 & $\begin{array}{l}\text { Low IgG } \\
\text { Miscellaneous }\end{array}$ & 1137 & 319 & {$[4,12]$} \\
\hline Toxo IgG/IgM Rapid Test ${ }^{\circledR}$ & Biopanda Reagents & 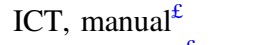 & & 1 & Miscellaneous & 310 & 170 & {$[8]$} \\
\hline Toxocell $^{\circledR}$ & Biokit & Agglutination $^{\mathfrak{f}}$ & & 1 & Miscellaneous & 589 & 344 & [26] \\
\hline Toxo HAI ${ }^{\circledR}$ & Fumouze & Hemagglutination $^{\mathfrak{f}}$ & & 1 & Miscellaneous & 589 & 344 & [26] \\
\hline Toxolatex $^{\circledR}$ & Fumouze & Agglutination $^{\mathfrak{f}}$ & & 1 & Miscellaneous & 589 & 344 & [26] \\
\hline Toxoplasma ICT IG/IgM ${ }^{\circledR}$ & LDBio & ICT, manual ${ }^{f}$ & & 3 & $\begin{array}{l}\text { Low IgG } \\
\text { Miscellaneous }\end{array}$ & 1492 & 559 & {$[2,8,13]$} \\
\hline Vidas Toxo $\operatorname{IgG}^{\circledR}$ & BioMérieux & ELFA, automated ${ }^{\mathfrak{f}}$ & $4 \leq x<8$ & 7 & $\begin{array}{l}\text { Low IgG } \\
\text { Miscellaneous } \\
\text { Pregnant women }\end{array}$ & 3368 & 1093 & $\begin{array}{c}{[4,7,10,14} \\
16,23,24]\end{array}$ \\
\hline Vitros ECiQ Toxoplasma IgG ${ }^{\circledR}$ & Ortho Diagnostics & CLIA $^{£}$ & $4 \leq x<8$ & 1 & Pregnant women & 719 & 551 & [11] \\
\hline WB Toxo IgGII ${ }^{\circledR}$ & LDBio & $\mathrm{WB}$, manual $^{£}$ & & 1 & $\begin{array}{l}\text { Low IgG } \\
\text { Miscellaneous }\end{array}$ & 569 & $162^{\mathfrak{f}}$ & {$[5]$} \\
\hline
\end{tabular}

${ }^{£}$ With comparison to Dye-Test available.

ELISA: enzyme-linked immuno-sorbent assay, MEIA: microparticle enzyme immunoassay, ELFA: enzyme-linked fluorescent assay, CLIA: chemiluminescence immunoassay, CMIA: chemiluminescent microparticle immunoassay, ECLIA: electrochemiluminescence immunoassay, MFA: Multiplex fluorescence assay, WB: western-blot assay, ICT: immunochromatographic assay. 
Table 2. Sensitivity, Specificity, PPV and NPV of anti-Toxoplasma IgG commercial assays included in the study.

\begin{tabular}{|c|c|c|c|c|c|}
\hline Assay & $\begin{array}{c}\text { Sensitivity } \\
\text { mean \% (range) }\end{array}$ & $\begin{array}{c}\text { Specificity } \\
\text { mean \% (range) }\end{array}$ & $\begin{array}{l}\text { PPV mean \% } \\
\quad \text { (range) }\end{array}$ & $\begin{array}{c}\text { NPV } \\
\text { mean \% (range) }\end{array}$ & Comments \\
\hline Access Toxo IgG II $^{\circledR}$ & $\begin{array}{c}89.7 \\
\text { Low IgG: } 13.4\end{array}$ & $\begin{array}{c}100 \\
\text { Low IgG: } 99.6\end{array}$ & 100 & 92.8 & \\
\hline Advia Centaur $^{\circledR}$ & $\begin{array}{c}100 \\
\text { Low IgG: } 51.1\end{array}$ & 100 & 100 & 100 & Single study \\
\hline Architect Toxo $\operatorname{IgG}{ }^{\circledR}$ & $\begin{array}{c}90.7(80.8-99.6) \\
\text { Low IgG: } 30.5(12-43.9)\end{array}$ & $\begin{array}{l}99.8(99.5-100) \\
\text { Low IgG: } 100\end{array}$ & $99.7(99.1-100)$ & $97.3(94.6-99.5)$ & $\begin{array}{l}\text { For low } \operatorname{IgG} \text {, one study did not provide } \\
\text { crude results }[13]\end{array}$ \\
\hline Axsym Toxo $\operatorname{IgG}^{\circledR}$ & $96.1(90.2-99.6)$ & $99.7(99.5-100)$ & $99.7(99.4-100)$ & $97.2(93.1-99.5)$ & \\
\hline BioPlex 2200 ToRCH IgG//gM ${ }^{\circledR}$ & 97.8 & 91.3 & 98.5 & 87.5 & Single study \\
\hline Elecsys Toxo $\operatorname{IgG}^{\circledR}$ & $\begin{array}{c}98.6(97.5-100) \\
\text { Low IgG: } 88.6(73.2-95.6)\end{array}$ & $\begin{array}{c}99.6(98.7-100) \\
\text { Low IgG: } 99.6(99.3-100)\end{array}$ & $99.2(98.3-100)$ & $99.4(98.7-100)$ & $\begin{array}{l}100 \% \text { concordance with DT for sera } \\
\text { with interfering diseases }\end{array}$ \\
\hline $\begin{array}{l}\text { Immulite } 2000 \text { anti-Toxoplasma } \\
\operatorname{IgG}^{\circledR}\end{array}$ & 93.5 (87.9-99) & $99.8(99.6-100)$ & 99.4 & 92.7 & \\
\hline Liaison Toxo IgG II $^{\circledR}$ & $\begin{array}{c}94.8(93.8-95.8) \\
\text { Low IgG: } 25.5(6.7-58.9)\end{array}$ & $\begin{array}{l}99.5 \text { (na) } \\
\text { Low IgG: } 100\end{array}$ & $98.2(96.8-99.5)$ & $97.4(95.7-99.1)$ & $\begin{array}{c}\text { One study merged results obtained with } \\
\text { low and standard IgG titers (58.9\% } \\
\text { sensitivity) }\end{array}$ \\
\hline Platelia Toxo $\operatorname{IgG}^{\circledR}$ & $\begin{array}{c}96.4(95.6-97.2) \\
\text { Low IgG: } 47.6(32.9-62.2)\end{array}$ & $\begin{array}{l}99.4(98.7-100) \\
\text { Low IgG: } 100\end{array}$ & $98.4(96.7-100)$ & $97.7(97.1-98.3)$ & $\begin{array}{c}\text { In one study, only } 29 / 56 \text { discrepant EIA } \\
\text { were confirmed by DT }\end{array}$ \\
\hline TGS TA Toxo IgG/IDS-iSYS ${ }^{\circledR}$ & $\begin{array}{c}97 \\
\text { Low IgG: } 46.3\end{array}$ & $\begin{array}{c}97 \\
\text { Low IgG: } 96.7\end{array}$ & $\begin{array}{c}\text { nd } \\
\text { Low IgG: } 86.4\end{array}$ & $\begin{array}{c}\text { nd } \\
\text { Low IgG: } 79.8\end{array}$ & \\
\hline Vidas Toxo $\operatorname{IgG}^{\circledR}$ & $\begin{array}{c}95.5 \text { (91.4-100) } \\
\text { Low IgG: } 44.2(12.2-63.3)\end{array}$ & $\begin{array}{l}99.8(99.5-100) \\
\text { Low IgG: } 99.7(99-100)\end{array}$ & $99.1(96.8-100)$ & $97.7(93.9-99.5)$ & \\
\hline Vitros ECiQ Toxoplasma $\operatorname{IgG}^{\circledR}$ & 93.4 & 100 & nd & nd & $\begin{array}{l}\text { Single study, no separate analysis of } \\
\text { IgG et IgM results }\end{array}$ \\
\hline Pastorex Toxo ${ }^{\circledR}$ & $\begin{array}{c}98.8 \\
\text { Low IgG: } 51.5\end{array}$ & 98.8 & 98.8 & 98.8 & $\begin{array}{l}\text { Single study, } 6.5 \% \text { false-positive with } \\
\text { interfering diseases, sensitivity } 97.3 \% \\
\text { and } 100 \% \text { in acute and chronic } \\
\text { toxoplasmosis, respectively }\end{array}$ \\
\hline Toxocell $^{\circledR}$ & $\begin{array}{c}96.8 \\
\text { Low IgG: } 66.7\end{array}$ & 97.6 & 97.6 & 96.8 & $\begin{array}{l}\text { Single study, } 11 \% \text { false-positive results } \\
\text { with interfering diseases, Sensitivity } \\
97.3 \% \text { and } 100 \% \text { in acute and chronic } \\
\text { toxoplasmosis, respectively }\end{array}$ \\
\hline Toxo HAI $^{\circledR}$ & $\begin{array}{c}100 \\
\text { Low IgG: } 97\end{array}$ & 99.2 & 99.2 & 100 & $\begin{array}{l}\text { Single study, } 4.3 \% \text { false-positive results } \\
\text { with interfering diseases, Sensitivity } \\
97.3 \% \text { and } 100 \% \text { in acute and chronic } \\
\text { toxoplasmosis, respectively }\end{array}$ \\
\hline
\end{tabular}


IgG detection (51.5\%-66.7\%) (Table 2). RDTs (OnSite Toxo IgG/IgM Combo Rapid Test ${ }^{\circledR}$, Toxo IgG/IgM Rapid Test ${ }^{\circledR}$ Biopanda, and Toxoplasma ICT IgG/IgM ${ }^{\circledR}$ LDBio) showed very good sensitivity, but two of them were evaluated only in the standard situation. Their performance to detect low IgG titers therefore needs further evaluation.

\section{Specificity}

The specificity of IgG assays on routine sera ranged from $91.3 \%$ to $100 \%$ (Table 2). Thirteen out of 20 assays had specificity $>99 \%$, of which 10 were EIA. Specificity for the detection of low IgG titers ranged from $96.7 \%$ to $100 \%$, but it was not evaluated in all studies. The apparent lack of sensitivity to detect low $\operatorname{IgG}$ titers was balanced by excellent specificity, being equal to or nearly $100 \%$ for Architect Toxo $\operatorname{IgG}^{\circledR}$, Platelia Toxo $\operatorname{IgG}^{\circledR}$, Vidas Toxo $\operatorname{IgG}^{\circledR}$, Elecsys Toxo $\operatorname{IgG}^{\circledR}$, and Liaison Toxo IgGII ${ }^{\circledR}$. Not surprisingly, methods with the poorest sensitivity in this setting, like the Liaison Toxo $\operatorname{IgGII}^{\circledR}$ or the Architect Toxo $\operatorname{IgG}^{\circledR}$ assays, had the highest specificity (Table 2).

The possible interference of non-specific immunoglobulins produced in various clinical contexts (auto-immune diseases, viral infections, etc.) was specifically addressed in only two studies $[24,26]$, which showed that EIA were very specific regarding such serum panels, while agglutination methods were more impacted, leading to $4.3 \%$ to $11 \%$ false-positive results.

\section{PPV and NPV}

PPV and NPV were reported or could be calculated from 11 studies [5, 7-10, 13, 14, 16, 24, 26] and are presented in Table 2. PPV and NPV varied from $97.1 \%$ to $100 \%$ and from $87.5 \%$ to $100 \%$, respectively, not taking into account studies focusing on low IgG results. Whereas the PPV was very good for most EIA and manual methods, the NPV appeared to be the more discriminant parameter among methods (Fig. 2).

\section{Kinetics of IgG detection after primary infection}

The ability to detect IgG early after primary infection was assessed in few studies [5, 7, 13, 16, 24]. Franck et al. showed on 101 sequential sera obtained during seroconversion, that Elecsys Toxo $\operatorname{IgG}^{\circledR}$ did not detect $\operatorname{IgG}$ in 8 out of 17 patients who tested positive with WB Toxo IgG II ${ }^{\circledR}$ [5]. Murat et al. compared the results obtained with Vidas, Architect and Liaison on 15 cases of seroconversion, and observed that Vidas and Architect were the last assays to become positive in 5 and 1 cases, respectively [16]. Gay-Andrieu et al. confirmed the longer delay in IgG detection by Vidas, compared to AxSYM and/ or Architect in 20 out of 28 cases of seroconversions (74 sequential serum samples) [7]. Interestingly, AxSYM tested positive prior to Architect in 8 out of 28 cases, while Architect tested positive prior to AxSYM in only 2 cases. When considering GZ results as positive, AxSYM tested positive prior to Architect in five cases, and Architect tested positive prior to AxSYM in three cases, while Vidas precocity was hardly improved. In the study by Mahinc et al. comparing the LDBio 

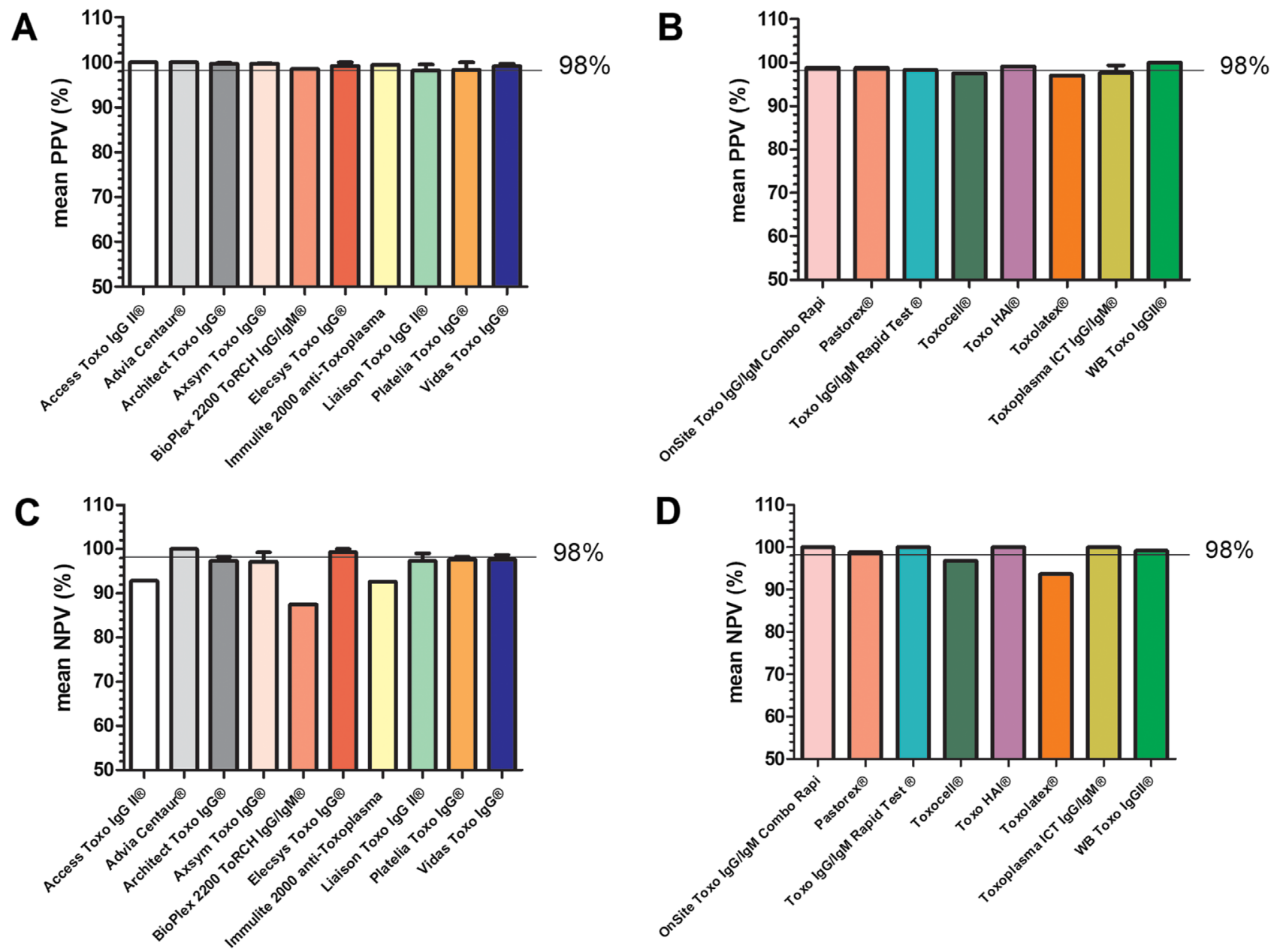

Figure 2. Positive predictive value (PPV) and negative predictive value (NPV) calculated for 10 anti-Toxoplasma IgG EIA assays (A, C) and 8 manual assays $(B, D)$ included in the study.

ICT assay to Architect, the ICT was positive in 16/50 cases, while only IgM were detected with Architect or Toxo-ISAGA (BioMérieux) [13]. Finally, Villard et al. compared the results obtained with several EIAs on a single early serum from 16 seroconversion cases, and showed that Advia Centaur and Elecsys constantly tested negative, while Architect, Platelia and Liaison detected IgG in 2, 2, and 1 cases, respectively [24]. Of note, Architect, Elecsys and Liaison yielded GZ results in 5, 14, and 1 additional cases, respectively.

\section{Ease of use}

The characteristics of the various serologic techniques are listed in Table 3. Overall, EIA assays need electricity and require specific skills and training of users, to ensure high quality results. Particularly, these techniques need calibration and assessment of reagents using negative and positive controls analyzed in each series or at least daily, when analyses are performed on demand on a multiparametric device. Additionally, these automated devices require regular maintenance operations by trained technicians, to ensure reliable results. Similarly, all reagents need cold chain shipment and storage in refrigerators, which can be a limiting factor in some countries. Microplate EIA can be performed manually (serum dilutions and reagents distribution, washing steps) but still need a spectrophotometer, preferably linked to a computer to calculate the results and avoid errors. The use of a microplate setup device is recommended to ensure reproducible results.

Agglutination assays are very easy to use and need no apparatus. WB assays are quite simple too, but require an oscillating agitator. All these kits must be kept at +4 to $8^{\circ} \mathrm{C}$.

The storage temperature and staff skills can be limiting factors in favor of immunochromatographic tests, which can be stored at room temperature, and can thus be used in primary care centers of low-income countries.

\section{Discussion}

The choice of a serological method for the diagnosis of toxoplasmosis is important, as it can have clinical consequences. Insight into the advantages and drawbacks of a given assay is crucial to guide complementary tests in some clinical settings, if needed. Other criteria that can help the choice of the assay are robustness, the need to obtain a quick result or to have trained staff, which can differ according to the population screened, the geographic location, and the resources of the laboratory, or the health care policy of the country. 
Agglutination tests can be used as complementary techniques in tertiary care laboratories or screening techniques in primary or secondary care centers, since they are easy to use and to implement. However, one must be aware of their limitations. Only four currently marketed assays have been thoroughly evaluated in only one study. It showed that the immuno-hemagglutination assay had the best sensitivity, including for low IgG titers, but this latter point was evaluated only on a small number of sera $(n=45)$ [26]. The latex agglutination assay Toxolatex $^{\circledR}$ had the lowest performances and should be avoided.

In laboratories in high or middle-income countries or possibly in tertiary care hospitals in low-income countries, the EIA assays offer the best performance/cadence ratio, and ensure reagent traceability together with storage of quality control data and maintenance and archiving of patient records on a dedicated server, compatible with the requirements for laboratory accreditation. Usually, standard curves make it possible to define a positive and negative threshold separated by a grey zone of undetermined results. In this context, the WB Toxo IgGII ${ }^{\circledR}$ is a frequently used method to confirm the specificity of GZ results obtained with these EIA techniques, as it showed perfect agreement with the DT gold standard technique, but unlike DT, does not require use of mice as a source of fresh Toxoplasma tachyzoites. Although quite easy to perform, this test is expensive and is not suitable for large-scale use as a screening method, but it is now established as a reference technique.

Some EIAs (Bioplex, Advia Centaur and Vitros) benefited from only one evaluation study, and would therefore need to be evaluated further. Particularly, Kasper et al. provided sensitivity and specificity rates on groups of sera known as $\mathrm{IgG}+/ \mathrm{IgM}+$ or $\mathrm{IgG}+/ \mathrm{IgM}-$, instead of separate analysis of $\mathrm{IgG}$ and $\operatorname{IgM}$ using Vitros [11]. This study was not excluded because it was the only one evaluating the Vitros system. The Bioplex assay is based on unique technology, and this first evaluation by Guigue et al. appeared disappointing, but needs confirmation [9]. The TGS/TA IDS-iSYS has a well-defined cut-off value with no GZ, avoiding problems with the interpretation of such results. Importantly, this GZ is the weakness of most EIAs, and manufacturers recommend considering GZ results as negative, since they can correspond to either false-positive or false-negative results. When specific IgM are simultaneously detected, GZ IgG results may correspond to a beginning of seroconversion, which led some authors to propose to lower the positivity threshold for some EIAs [15] or to immediately confirm IgG titers below or within the GZ using the WB Toxo $\operatorname{IgGII}^{\circledR}$, to allow earlier diagnosis and treatment of pregnant women. Armengol et al. [1] showed that the WB Toxo IgGII ${ }^{\circledR}$ can detect specific IgG one week before Elecsys Toxo $\operatorname{IgG}^{\circledR}$ and 2-3 weeks before most other EIAs. However, without a positive IgM result, this practice is not recommended. Reasonably, we presented only the performances of these assays, considering GZ results as negative, and recalculated authors' data when necessary, to ensure a fair comparison between all assays. Some authors provided sensitivity, specificity, PPV and NPV values for both situations, i.e. considering GZ results as true-positive or true-negative, and showed huge variations, particularly for sera with low IgG titers [4, 14]. Only two studies addressed specifically the issue of detecting low IgG titers $[4,23]$. In this 
specific situation, apart from the WB Toxo $\operatorname{IgG}$ II $^{\circledR}$, the Elecsys Toxo $\mathrm{IgG}^{\circledR}$ assay performed fairly well. This ability of Elecsys to detect low IgG amounts may seem contradictory with its delay to detect IgG following primary infection, and is probably linked to the antigenic mix used in this assay, which is probably enriched in parasite cytoplasmic antigens rather than surface antigens.

For all EIAs except Bioplex and TGS/TA, the specificity exceeded $99 \%$, which is not surprising, as these assays usually rely on immunocapture methods. However, Simon et al. recently explored the question of false-positive results obtained with Architect Toxo $\operatorname{IgG}^{\circledR}$, and found that $60 \%$ were due to cross-reaction with the parasite recombinant proteins GRA7 and GRA8; they suggest that exposure to closely related parasites, such as Hammondia hammondi or Neospora caninum, could explain these false-positive results [22]. Interfering immunoglobulins are mainly IgM, thus IgG EIAs infrequently suffer from non-specific reactions. In contrast, agglutination methods are more prone to false-positive results due to interfering diseases, such as viral infections and auto-immune diseases, particularly latex agglutination (Pastorex ${ }^{\circledR}$ Toxo, Toxocell ${ }^{\circledR}$ latex, Toxolatex ${ }^{\circledR}$ ) which detects both IgG and IgM.

Two of the recently developed RDTs showed similar performance characteristics albeit in a single study [8]. The overall sensitivity of the three rapid tests was $100 \%$, but some falsepositive results may be observed. They have the advantage of detecting both isotypes allowing diagnosis of recent infection.

The reliability of IgG detection has important clinical implications, as it enables the user to consider a woman as immunized when performed at the beginning of pregnancy, to consider the diagnosis of Toxoplasma reactivation in an immunocompromized patient, and to identify seropositive organ donors who could transmit infection to seronegative transplant recipients. In the first situation, the specificity and the PPV are of utmost importance, while in the second situation, the NPV is crucial to exclude the diagnosis. Consequently, PPV and NPV are paramount indicators, depending on the population screened. In low-resource countries facing HIV-associated opportunistic infections, the ideal technique should ally affordability, ease-of-use on bedside, storage at room temperature, and excellent NPV to rule out diagnosis. In this setting, an immunochromatographic test would be best suited, and has the advantage of detecting both specific isotypes, thus affording the diagnosis of recently acquired as well as reactivation infections. For screening of pregnant women at antenatal care centers, both immunochromatographic tests and hemagglutination methods would be suitable to determine the serologic status at the beginning of pregnancy, and provide hygiene recommendations to those who are seronegative.

In high-income countries, the main categories of patients targeted for serological diagnosis are pregnant women and transplant recipients or organ donors. The challenge is to have a technique that provides a positive result with the highest degree of confidence, so that a pregnant woman can be definitively considered immunized and protected. This also allows healthcare professionals to guide chemoprophylaxis according to transplant recipient and organ donor serostatus. In these settings, EIAs which have a high PPV are the most appropriate techniques, all the more so as they are integrated in multiparameter automated systems with high cadence adapted to emergencies. In these patient populations, specific IgM detection is an important complementary parameter to rule out recent infection and guide treatment or patient management (transplantation delay, amniocentesis) [20].

Altogether, the choice of a serological assay to detect antiToxoplasma IgG must be weighed, and medical biologists should be aware of the pitfalls of their technique and seek advice from a reference laboratory when needed [25]. The pitfalls and advantages of these assays may help to tailor implementation of Toxoplasma serologic screening in developing countries as part of essential in vitro diagnostics for advanced HIV, as recently advocated by international experts [3].

\section{Supplementary Material}

The supplementary material of this article is available at https://www.parasite-journal.org/10.1051/parasite/2021035.

Supplementary Table 1: Number of references retrieved according to search terms using PubMed and Web of Science database.

\section{Conflict of interest}

Author declared no conflict of interests.

\section{Funding}

The authors received no specific funding for this work.

\section{References}

1. Armengol C, Cassaing S, Roques-Malecaze C, Chauvin P, Iriart X, Berry A, Fillaux J. 2017. Time before anti-Toxoplasma IgG seroconversion detection by 7 commercial assays in French pregnant women. Diagnostic Microbiology and Infectious Disease, 87, 103-107.

2. Begeman IJ, Lykins J, Zhou Y, Lai BS, Levigne P, El Bissati K, Boyer K, Withers S, Clouser F, Noble AG, Rabiah P, Swisher CN, Heydemann PT, Contopoulos-Ioannidis DG, Montoya JG, Maldonado Y, Ramirez R, Press C, Stillwaggon E, Peyron F, McLeod R. 2017. Point-of-care testing for Toxoplasma gondii IgG/IgM using Toxoplasma ICT IgG-IgM test with sera from the United States and implications for developing countries. PLoS Neglected Tropical Diseases, 11, e0005670.

3. Bongomin F, Govender NP, Chakrabarti A, Robert-Gangneux F, Boulware DR, Zafar A, Oladele RO, Richardson MD, Gangneux J-P, Alastruey-Izquierdo A, Bazira J, Boyles TH, Sarcarlal J, Nacher M, Obayashi T, Worodria W, Pasqualotto AC, Meya DB, Cheng B, Sriruttan C, Muzoora C, Kambugu A, Rodriguez Tudela JL, Jordan A, Chiller TM, Denning DW. 2019. Essential in vitro diagnostics for advanced HIV and serious fungal diseases: international experts' consensus recommendations. European Journal of Clinical Microbiology \& Infectious Diseases, 38, 1581-1584.

4. Douet T, Armengol C, Charpentier E, Chauvin P, Cassaing S, Iriart X, Berry A, Fillaux J. 2019. Performance of seven commercial automated assays for the detection of low levels of anti-Toxoplasma $\operatorname{IgG}$ in French immunocompromised patients. Parasite, 26, 51. 
5. Franck J, Garin YJ-F, Dumon H. 2008. LDBio-Toxo II immunoglobulin $G$ Western blot confirmatory test for antitoxoplasma antibody detection. Journal of Clinical Microbiology, 46, 2334-2338.

6. Gajurel K, Dhakal R, Montoya JG. 2015. Toxoplasma prophylaxis in haematopoietic cell transplant recipients: a review of the literature and recommendations. Current Opinion in Infectious Diseases, 28, 283-292.

7. Gay-Andrieu F, Fricker-Hidalgo H, Sickinger E, Espern A, Brenier-Pinchart M-P, Braun H-B, Pelloux H. 2009. Comparative evaluation of the ARCHITECT Toxo IgG, IgM, and IgG Avidity assays for anti-Toxoplasma antibodies detection in pregnant women sera. Diagnostic Microbiology and Infectious Disease, 65, 279-287.

8. Gomez CA, Budvytyte LN, Press C, Zhou L, McLeod R, Maldonado Y, Montoya JG, Contopoulos-Ioannidis DG. 2018. Evaluation of three point-of-care tests for detection of Toxoplasma immunoglobulin IgG and $\operatorname{IgM}$ in the United States: Proof of concept and challenges. Open Forum. Infectious Diseases, 5, ofy 215.

9. Guigue N, Menotti J, Hamane S, Derouin F, Garin YJ-F. 2014. Performance of the BioPlex 2200 flow immunoassay in critical cases of serodiagnosis of toxoplasmosis. Clinical and Vaccine Immunology, 21, 496-500.

10. Hofgärtner WT, Swanzy SR, Bacina RM, Condon J, Gupta M, Matlock PE, Bergeron DL, Plorde JJ, Fritsche TR. 1997. Detection of immunoglobulin $\mathrm{G}$ (IgG) and $\mathrm{IgM}$ antibodies to Toxoplasma gondii: evaluation of four commercial immunoassay systems. Journal of Clinical Microbiology, 35, 3313-3315.

11. Kasper DC, Prusa AR, Hayde M, Gerstl N, Pollak A, Herkner KR, Reiter-Reisacher R. 2009. Evaluation of the Vitros ECiQ immunodiagnostic system for detection of anti-Toxoplasma immunoglobulin $G$ and immunoglobulin $M$ antibodies for confirmatory testing for acute Toxoplasma gondii infection in pregnant women. Journal of Clinical Microbiology, 47, 164-167.

12. Levigne P, Peyron F, Wallon M. 2016. Assessment of the diagnostic performance of the IDS-iSYS tests for toxo IgG, toxo IgM and avidity. Diagnostic Microbiology and Infectious Disease, 86, 148-152.

13. Mahinc C, Flori P, Delaunay E, Guillerme C, Charaoui S, Raberin H, Hafid J, L'Ollivier C. 2017. Evaluation of a new immunochromatography technology test (LDBio Diagnostics) to detect Toxoplasma IgG and IgM: Comparison with the routine Architect technique. Journal of Clinical Microbiology, 55, 3395-3404.

14. Maudry A, Chene G, Chatelain R, Patural H, Bellete B, Tisseur B, Hafid J, Raberin H, Beretta S, Sung RTM, Belot G, Flori P. 2009. Bicentric evaluation of six anti-Toxoplasma immunoglobulin $\mathrm{G}$ (IgG) automated immunoassays and comparison to the Toxo II IgG Western blot. Clinical and Vaccine Immunology, 16, 1322-1326.

15. Mouri O, Kendjo E, Touafek F, Fekkar A, Konte O, Imbert S, Courtin R, Mazier D, Paris L. 2015. The impact of lowering the cut-off value on the sensitivity of the Platelia Elisa IgG (Bio-Rad) test for toxoplasmosis diagnosis. Parasite, 22, 22.

16. Murat J-B, Dard C, Fricker Hidalgo H, Dardé M-L, BrenierPinchart M-P, Pelloux H. 2013. Comparison of the Vidas system and two recent fully automated assays for diagnosis and follow-up of toxoplasmosis in pregnant women and newborns. Clinical and Vaccine Immunology, 20, 1203-1212.

17. Petithory JC, Ambroise-Thomas P, De Loye J, Pelloux H, Goullier-Fleuret A, Milgram M, Buffard C, Garin JP. 1996. Le sérodiagnostic de la toxoplasmose: étude comparative multicentrique d'une gamme étalon, par les différents tests actuels et avec expression des résultats en unités internationales. Groupe de travail toxoplasmose du Contrôle national de qualité en parasitologie, Syndicat des fabricants de réactifs de laboratoire, Groupe de travail standardisation des tests sérologiques du Réseau européen de lutte contre la toxoplasmose congénitale. Bulletin of the World Health Organization, 74, 291-298.

18. Prusa A-R, Hayde M, Unterasinger L, Pollak A, Herkner KR, Kasper DC. 2010. Evaluation of the Roche Elecsys Toxo IgG and IgM electrochemiluminescence immunoassay for the detection of gestational Toxoplasma infection. Diagnostic Microbiology and Infectious Disease, 68, 352-357.

19. Robert-Gangneux F, Bourhis C, Chevrier S, Gangneux J-P. 2009. Evaluation of DPC immulite 2000 Toxoplasma quantitative $\mathrm{IgG} / \mathrm{IgM}$ kits for automated toxoplasmosis serology with immulite 2000. Journal of Clinical Laboratory Analysis, 23, $336-340$.

20. Robert-Gangneux F, Dardé M-L. 2012. Epidemiology of and diagnostic strategies for toxoplasmosis. Clinical Microbiology Reviews, 25, 264-296.

21. Robert-Gangneux F, Meroni V, Dupont D, Botterel F, Garcia JMA, Brenier-Pinchart M-P, Accoceberry I, Akan H, Abbate I, Boggian K, Bruschi F, Carratalà J, David M, Drgona L, Djurković-Djaković O, Farinas MC, Genco F, GkraniaKlotsas E, Groll AH, Guy E, Hirzel C, Khanna N, Kurt Ö, Junie LM, Lazzarotto T, Len O, Mueller NJ, Munoz P, Pana ZD, Roilides E, Stajner T, van Delden C, Villena I, Pelloux H, Manuel O. 2018. Toxoplasmosis in transplant recipients, Europe, 2010-2014. Emerging Infectious Diseases, 24, 14971504.

22. Simon L, Fillaux J, Guigon A, Lavergne R-A, Villard O, Villena I, Marty P, Pomares C, Toxoplasma p35 Study Group. 2020. Serological diagnosis of Toxoplasma gondii: analysis of false-positive IgG results and implications. Parasite, 27, 7.

23. de Souza GF, Carvalho D, Pedrosa W, Franck J, Piarroux R. 2012. Analytical validation of anti-toxoplasma IgG immunoassays. Brazilian Journal of Infectious Diseases, 16, 574-576.

24. Villard O, Cimon B, L'Ollivier C, Fricker-Hidalgo H, Godineau N, Houze S, Paris L, Pelloux H, Villena I, Candolfi E. 2016. Help in the choice of automated or semiautomated immunoassays for serological diagnosis of toxoplasmosis: Evaluation of nine immunoassays by the French national reference center for toxoplasmosis. Journal of Clinical Microbiology, 54, 30343042.

25. Villard O, Cimon B, L'Ollivier C, Fricker-Hidalgo H, Godineau N, Houze S, Paris L, Pelloux H, Villena I, Candolfi E. 2016. Serological diagnosis of Toxoplasma gondii infection: Recommendations from the French national reference center for toxoplasmosis. Diagnostic Microbiology and Infectious Disease, 84, 22-33.

26. Villard O, Cimon B, Franck J, Fricker-Hidalgo H, Godineau N, Houze S, Paris L, Pelloux H, Villena I, Candolfi E, Network from the French National Reference Center for Toxoplasmosis. . 2012. Evaluation of the usefulness of six commercial agglutination assays for serologic diagnosis of toxoplasmosis. Diagnostic Microbiology and Infectious Disease, 73, 231-235.

27. Zhang K, Lin G, Han Y, Li J. 2017. The standardization of 5 immunoassays for anti-Toxoplasma immunoglobulin $\mathrm{G}$ (IgG). Clinica Chimica Acta, 472, 20-25.

Cite this article as: Robert-Gangneux F \& Guegan H. 2021. Anti-Toxoplasma IgG assays: What performances for what purpose? A systematic review. Parasite 28, 39. 
An international open-access, peer-reviewed, online journal publishing high quality papers on all aspects of human and animal parasitology

Reviews, articles and short notes may be submitted. Fields include, but are not limited to: general, medical and veterinary parasitology; morphology, including ultrastructure; parasite systematics, including entomology, acarology, helminthology and protistology, and molecular analyses; molecular biology and biochemistry; immunology of parasitic diseases; host-parasite relationships; ecology and life history of parasites; epidemiology; therapeutics; new diagnostic tools.

All papers in Parasite are published in English. Manuscripts should have a broad interest and must not have been published or submitted elsewhere. No limit is imposed on the length of manuscripts.

Parasite (open-access) continues Parasite (print and online editions, 1994-2012) and Annales de Parasitologie Humaine et Comparée (1923-1993) and is the official journal of the Société Française de Parasitologie. 